\title{
Occurrence and microbial dynamics of macroscopic organic aggregates (lake snow) in Lake Kinneret, Israel, in fall
}

\author{
Hans-Peter Grossart ${ }^{1, *}$, Tom Berman ${ }^{2}$, Meinhard Simon $^{1}$, Kirsten Pohlmann ${ }^{1}$ \\ ${ }^{2}$ Limnological Institute of the University of Constance, PO Box 5560, D-78434 Konstanz, Germany \\ ${ }^{2}$ Israel Oceanographic \& Limnological Research, Yigal Allon Kinneret Limnological Laboratory, PO Box 345, \\ Tiberias, Israel 14102
}

\begin{abstract}
The occurrence, composition, and microbial dynamics of lake snow aggregates were studied in Lake Kinneret, Israel, in fall 1995 (September-December). Mechanisms of formation and bacterial colonization of aggregates were investigated under well-defined conditions by using rolling tanks. Abundance, form, and composition of aggregates in Lake Kinneret were controlled by biological as well as by physical parameters such as the phytoplankton standing stock and wind-induced shear forces. In meso-eutrophic Lake Kinneret, the abundance of aggregates ranged between $<1$ and $100 \mathrm{l}^{1}$ and numbers of transparent exopolymer particles (TEP) reached up to $6915 \mathrm{ml}^{-1}$ Our laboratory experiments using natural lake water samples indicated that cations, particulate organic carbon (POC), and TEP controlled aggregation. According to differences in formation and composition of aggregates. their bacterial colonization was highly variable; colonization was highest on cyanobacterial aggregates. High aminopeptidase activities of aggregate-associated bacteria indicated a rapid turnover of particulate organic matter (POM) and led to a release of dissolved amino acids into the ambient water Efficient grazing of lake snow aggregates by juvenile fish from Lake Kinneret (Acanthobrama terraesanctae and $A$. lissneri) suggested that POM on aggregates can be directly transferred to higher trophic levels. Thus, aggregates with associated microorganisms are not only sites of vertical fluxes, centers of rapid and efficient recycling of POM, and a source of dissolved organic matter (DOM), but also a potentially important food source for higher trophic levels.
\end{abstract}

KEY WORDS: Lake snow aggregates - Lake Kinneret - Bacteria - Aggregate formation - POM - TEP · Ectoenzyme activities. Fish feeding

\section{INTRODUCTION}

Macroscopic organic aggregates, known as marine snow, have been studied intensively in the ocean (see reviews by Fowler \& Knauer 1986, Alldredge \& Silver 1988). They have been identified as an integral part of marine ecosystems for many reasons; due to their enhanced size and sinking velocity they are responsible for most of the downward vertical mass flux. Furthermore, marine snow aggregates are rich in inor-

\footnotetext{
- Present address: Marine Biology Research Division, Scripps Institution of Oceanography, University of California, San Diego, La Jolla, California 92093-0202, USA.

E-mail: hgrossart@ucsd.edu
}

ganic and organic nutrients (Shanks \& Trent 1979, Herndl 1992), making them important sites for biological processes of production, decomposition, and nutrient recycling in the water column. Marine snow aggregates are colonized by algae and a rich and diverse detrital community of bacteria and protozoans, usually at concentrations many-fold higher than in the surrounding water (Alldredge \& Cox 1982, Prézelin \& Alldredge 1983). Beside being microhabitats for microorganisms with unique chemical properties (Alldredge \& Cohen 1987) they are also food sources for large particle feeders such as fish and zooplankton (Alldredge 1979. Urrère \& Knauer 1981, Larson \& Shanks 1996).

However, relatively few investigations have examined the role of macroscopic organic aggregates in 
lakes. A major reason for this gap is the difficulty of sampling. Since large aggregates are very fragile they are destroyed by conventional water sampling and further processing such as filtration. By adapting sampling techniques from marine studies on the basis of SCUBA diving, Grossart \& Simon (1993) were able to demonstrate for the first time the occurrence of macroscopic organic aggregates in a lake, Lake Constance, Germany. These and subsequent results (Grossart et al. 1997, Grossart \& Simon unpubl, a, b) indicate that the significance and ecological role of macroscopic organic aggregates are very similar in lakes and in the ocean.

In this study we investigated the occurrence, composition, and microbial dynamics of lake snow aggregates in Lake Kinneret, Israel, between September and December 1995. We also studied mechanisms of formation of aggregates and their bacterial colonization under well-defined conditions in experimenls using rolling tanks (Shanks \& Edmondson 1989).

\section{MATERIAL AND METHODS}

Study sites. Studies in Lake Kinneret were carried out from September to December 1995 at 2 sites: (1) at a central station of the lake with a maximum depth of $43 \mathrm{~m}$ and (2) at the shore in front of the Kinneret Limnological Laboratory to a maximum depth of $6 \mathrm{~m}$. Lake Kinneret is a meso-eutrophic, warm-monomictic lake which has an anoxic hypolimnion during thermal stratification from May until December. The most important characteristics of Lake Kinneret are summarized in Table 1. The littoral zone of Lake Kinneret is mostly free of macrophytes. A pronounced feature of the lake is the mass development of Peridinium gatunense from March to May (Berman et al. 1995) and the relatively low abundance of diatoms throughout the year. Nanoplanktonic chlorophyta are usually dominant from July through December. In 1995, a filamentous cyanobacterium Aphanizomenon ovalisporum was also present from mid-July to November, contributing up to $30 \%$ of total phytoplankton biomass. In October 1995 colonyforming cyanobacteria Microcystis spp. were abundant from 0 lo $6 \mathrm{mi}$ depth. The cyanobacteria disappeared when strong winds occurred at the beginning of November and were followed by a short bloom of diatoms Melosira granulata.

Abundance and characterization of aggregates. The abundance of macroscopic organic aggregates (agg, $\geq 3 \mathrm{~mm}$ ) was determined in situ during 3 or 4 SCUBA dives $w k^{-1}$ at various depths in 2 ways: (1) at low abundances (<5 agg $1^{-1}$ ) aggregates were counted visually, (2) at higher abundances aggregates were counted on photographs taken at the sampling depths. The sam- pling depth ranged between 0 and $43 \mathrm{~m}$. For further details see Grossart \& Simon (1993). Individual aggregates were collected in $6 \mathrm{ml}$ open-ended syringes (Gotschalk \& Alldredge 1989) during the same dives. The aggregates were stored in the syringes for less than $2 \mathrm{~h}$ in a cooling box until further analysis. All sampled aggregates were categorized microscopically with respect to their morphology and composition.

Formation of aggregates. To study the time of aggregate formation, water samples from $1 \mathrm{~m}$ depth were incubated in $1 \mathrm{I}$ rolling tanks at 2 rpm (Shanks \& Edmondson 1989j. The process of aggregation was examined periodically and the time of formation defined as the period after which 1 or more aggregates $\geq 3 \mathrm{~mm}$ in diameter occurred. In order to get an idea of the potential of Peridinium gatunense to form aggregates during the spring bloom, pure cultures of this alga were also incubated in the rolling tanks. The formation of large aggregatcs in rolling tanks was experimentally manipulated (3,12 and 18 October) by adding high concentrations of EDTA ( $4 \mathrm{mM}$ final concentration) to the water samples to remove free cations.

Chemical and biological parameters. Particulate matter (PM), particulate organic carbon (POC), transparent exopolymer particles (TEP), phytoplankton and zooplankton species composition of aggregates and water samples were determined by methods described in Grossart et al. (1997). PM and POC were measured by using filtration, drying, and combustion (Jones 1979), and phytoplankton and zooplankton species were identified by using inverted light microscopy (Utermöhl 1958). TEP was counted microscopically after alcian blue staining (Logan et al. 1994) at 100 and $400 \times$ magnification with a Zeiss Axioskop microscope.

Dissolved free amino acids (DFAA) were determined fluorometrically as primary amines after derivatization with o-phthaldialdehyde (OPA) (Parsons et al. 1984). Dissolved combined (DCAA) and particulate combined amino acids (PCAA) were hydrolyzed in doubledistilled $6 \mathrm{~N} \mathrm{HCl}$ for $20 \mathrm{~h}$ at $110^{\circ} \mathrm{C}$ prior to derivatization with OPA. Ammonium was removed after hydrolysis by adding $0.02 \mathrm{~N} \mathrm{NaOH}$ and subsequent evaporation below $40^{\circ} \mathrm{C}$.

Bacterial numbers. Bacteria were enumerated by epifluorescence microscopy (Zeiss Axioskop, 1000x magnification) after DAPI staining (Porter \& Feig 1980). To count free-living bacteria $1 \mathrm{ml}$ of water was filtered onto a $0.2 \mu \mathrm{m}$ Nuclepore filter. Aggregate associated bacteria were detached by ultrasonic treatment in $2 \mathrm{ml}$ of particle-free water containing $2 \mathrm{mM} \mathrm{Na}$ pyrophosphate (Velji \& Albright 1986) before filtration.

Bacterial activity. Respiring bacteria were identified by staining $5 \mathrm{ml}$ for $1 \mathrm{~h}$ with $5 \mathrm{mM}$ (final concentration) 5-cyano-2,3-ditolyltetrazoliumchloride (CTC, Polyscience-Inc., USA). Using the dual staining approach 
Table 1. Important properties of Lake Constance and Lake Kinneret. Data for Lake Constance are mostly provided by the Limnological Institute of the University of Konstanz, those for Lake Kinneret are from Serruya (1978) and Berman et al. (1992)

\begin{tabular}{|c|c|c|}
\hline Parameter & Lake Constance & Lake Kinneret \\
\hline Age & Pleistocene relict lake & Tertiary relict lake \\
\hline Years in present form & 10000 & 20000 \\
\hline Location & $47^{\circ} \mathrm{N}, 9^{\circ} \mathrm{E}$ & $33^{\circ} \mathrm{N}, 35.5^{\circ} \mathrm{E}$ \\
\hline Altitude & $395 \mathrm{~m}$ & $-209 \mathrm{~m}$ \\
\hline Watershed & $10900 \mathrm{~km}^{2}$ & $2730 \mathrm{~km}^{2}$ \\
\hline Surface area & $571 \mathrm{~km}^{2}$ & $170 \mathrm{~km}^{2}$ \\
\hline Maximum depth & $254 \mathrm{~m}$ & $43 \mathrm{~m}$ \\
\hline Mean depth & $100 \mathrm{~m}$ & $24 \mathrm{~m}$ \\
\hline Volume & $48.3 \mathrm{~km}^{3}$ & $4 \mathrm{~km}^{3}$ \\
\hline Mixis & Warm, monomictic & Warm, monomictic \\
\hline \multirow[t]{2}{*}{ Water temperature: } & $>22^{\circ} \mathrm{C}$ & $>28^{\circ} \mathrm{C}$ \\
\hline & $4-5^{\circ} \mathrm{C}$ & $15^{\circ} \mathrm{C}$ \\
\hline Seasonal thermocline & $6-15 \mathrm{~m}$ and $15-30 \mathrm{~m}$ & $16-30 \mathrm{~m}$ \\
\hline \multirow{3}{*}{$\begin{array}{ll}\text { Wind speeds: } & \text { Winter average } \\
& \text { Summer average } \\
& \text { Maximum }\end{array}$} & $3.5 \mathrm{~m} \mathrm{~s}^{-1}$ & $2.8 \mathrm{~m} \mathrm{~s}^{-1}$ \\
\hline & $2.2 \mathrm{~m} \mathrm{~s}^{-1}$ & $3.8 \mathrm{~m} \mathrm{~s}^{1}$ \\
\hline & $35 \mathrm{~m} \mathrm{~s}^{-1}$ & $15 \mathrm{~m} \mathrm{~s}^{-1}$ \\
\hline \multirow[t]{2}{*}{ Oxygen } & $8.8-19.5 \mathrm{mg} \mathrm{l}^{-1}$ & $0-13.6 \mathrm{mg} \mathrm{I}^{-1}$ \\
\hline & & Anoxic hypolimnion (stratified) \\
\hline Maximum chloride & $7 \mathrm{mg} \mathrm{l}^{-1}$ & $205-240 \mathrm{mg} \mathrm{l}^{-1}$ \\
\hline Sodium & $5 \mathrm{mg} \mathrm{l}^{-1}$ & $105-106 \mathrm{mgl}^{-1}$ \\
\hline Total phosphorus & $<10-60 \mu \mathrm{g} \mathrm{I}^{-1}$ & $13-38 \mu \mathrm{gl}^{-1}$ \\
\hline $\mathrm{PO}_{4}-\mathrm{P}$ & $<3-50 \mathrm{Hg} \mathrm{l}^{-1}$ & $<2-24 \mu \mathrm{g} \mathrm{I}^{-1}$ \\
\hline $\mathrm{NO}_{3}-\mathrm{N}$ & $0.2-0.8 \mathrm{mg} \mathrm{l}^{-1}$ & $<0.004-0.267 \mathrm{mg} \mathrm{l}^{-1}$ \\
\hline Silicate & $0.05-1.6 \mathrm{mg} \mathrm{l}^{-1}$ & $13 \mathrm{mg} \mathrm{l}^{-1}$ \\
\hline Calcium & $50 \mathrm{mg} \mathrm{l}^{-1}$ & $39.6-57.7 \mathrm{mg} \mathrm{l}^{-1}$ \\
\hline Mean primary productivity & $0.7 \mathrm{~g} \mathrm{C} \mathrm{m}^{-2} \mathrm{~d}^{-1}$ & $1.2-2.3 \mathrm{~g} \mathrm{C} \mathrm{m}^{-2} \mathrm{~d}^{-1}$ \\
\hline \multirow[t]{2}{*}{ Special features } & Summer storms & Few macrophytes \\
\hline & $\left(20-25 \mathrm{~m} \mathrm{~s}^{-1}\right)$ & $\begin{array}{l}\text { Periodic winds in summer } \\
\text { and fall }\left(10-15 \mathrm{~m} \mathrm{~s}^{-1}\right)\end{array}$ \\
\hline
\end{tabular}

with CTC and DAPI simultaneously it was possible to determine the percentage of respiring bacteria. The protocol of Schaule et al. (1993) was slightly modified and no nutrients were added to the sample.

Aminopeptidase activity was investigated by $1 \mathrm{~h}$ dark incubation at in situ temperature with L-leucine4-methyl-7-coumarinylamide (Leu-MCA, Fluka, Switzerland) according to Hoppe et al. (1988) but slightly modified. The saturation concentration of Leu-MCA was $50 \mu \mathrm{M}$ for free-living bacteria and 250 to $500 \mu \mathrm{M}$ for attached bacteria. Ten aggregates were pooled in $5 \mathrm{ml}$ of surrounding water before incubation. The activity of aggregate-associated bacteria was calculated as the total activity minus that of free-living bacteria.

Bacterial production (BP) was measured by the incorporation of ${ }^{14} \mathrm{C}$-leucine (Leu) (Kirchman et al. 1985, Simon \& Azam 1989). For free-living bacteria BP was determined by incubating $5 \mathrm{ml}$ samples with Leu (312 $\mathrm{mCi} \mathrm{mmol}^{-1}$, Amersham) at a final concentration of $30 \mathrm{nM}$. To measure production of attached bacteria 10 aggregates were pooled in $5 \mathrm{ml}$ of particle-free water and incubated with Leu at a final concentration of 60 to $125 \mathrm{nM}$. Triplicate samples and a Formalin- killed control ( $2 \%$ final concentration) were incubated in the dark at in situ temperature and uptake was stopped after $1 \mathrm{~h}$ with Formalin. Samples were filtered onto $0.45 \mu \mathrm{m}$ cellulose nitrate filters, extracted for 5 min with $5 \%$ ice-cold trichloroacetic acid, and radioassayed thereafter. Incorporation of Leu was converted into carbon produced via bacterial protein production (BPP-C) according to Simon \& Azam (1989), assuming a 2-fold isotope dilution for Leu.

Release of amino acids. Lake snow aggregates were incubated in a $12: 12 \mathrm{~h}$ dark-light cycle at in situ temperature in $30 \mathrm{ml}$ glass syringes filled with $0.2 \mu \mathrm{m}$ prefiltered lake water. Sedimentation during incubation was prevented by careful, vertical rotation at $2 \mathrm{rpm}$, keeping the aggregates always in a completely suspended state. The net release of amino acids was measured in 3 replicates and 1 control as the concentration difference in the surrounding water after various times of incubation. Only 1 experiment on $11 \mathrm{Sep}-$ tember 1995 was carried out.

Fish feeding experiments. Juvenile $(0+)$ Kinneret bleak (Acanthobrama terrae-sanctae and A. lissneri), approximately $10 \mathrm{~cm}$ in size, were kept in holding tanks that were constantly supplied with fresh lake 
water. Fishes were put into small experimental aquaria filled with 250 or $500 \mathrm{ml}$ of $100 \mu \mathrm{m}$-prefiltered lake water for at least $3 \mathrm{~h}$ prior to experiments. Aggregates from natural lake water and from a culture of Aphanizomenon ovalisporum were added by an Eppendorf pipette with a cut-off tip and were kept in suspension by repeated careful stirring. The feeding behavior of the fish was recorded from above by a video camera (Sony) and recorder (Panasonic). The composition and POC content of food aggregates and of fish fecal pellets produced after feeding on aggregates were determined as described above. Ten food aggregates or fish fecal pellets were pooled together prior to filtration and analysis.

\section{RESULTS}

\section{Abundance, composition and size of aggregates}

The abundance of lake snow aggregates in Lake Kinneret during fall 1995 was highly variable and ranged between $<1$ and $100 \mathrm{agg}^{-1}$. Highest numbers were found between 15 and $25 \mathrm{~m}$ depth at the beginning of November during a storm which terminated a small bloom of Melosira granulata. After strong winds on 10 October, 60 to 80 agg $1^{-1}$ were found at $5 \mathrm{~m}$ depth in the littoral zone. Numbers of aggregates in the littoral exhibited diurnal dynamics with highest numbers $\left(80 \mathrm{agg}^{-1}\right)$ in the afternoon after the regular daily winds and lower numbers $\left(<30 \mathrm{agg} \mathrm{l}^{-1}\right)$ in the morning. Numbers of Microcystis-derived aggregates were around $35 \mathrm{agg}^{-1}$ and were observed between 0 and $6 \mathrm{~m}$ depth at both sampling sites from September until the beginning of November. Usually numbers of aggregates were higher at the station close to the shore than at the central sampling site.

Five types of aggregates could be identified: (1) aggregates composed of colony-forming cyanobacteria Microcystis spp., (2) aggregates of filamentous cyanobacteria Aphanizomenon ovalisporum and of green algae (Scenedesmus quadricauda var., Staurastrum paradoxum, etc.), (3) aggregates of filamentous diatoms Melosira granulata, (4) aggregates of miscellaneous and unidentifiable matter in the anoxic zone with dense bacterial colonization, and (5) aggregates in the littoral zone composed of miscellaneous matter, benthic and pelagic algae. The absence of zooplankton-derived matter such as fecal pellets, molts, and carcasses in all aggregates examined was remarkable but may have been a seasonal phenomenon.

The size of aggregates varied between 3 and $30 \mathrm{~mm}$ in diameter. The largest aggregates were found either close to the shore or in the deepest part of the lake $(43 \mathrm{~m})$ and reached 30 and $25 \mathrm{~mm}$ in diameter, respec- tively. Aggregates of Melosira granulata were fragile and comet-shaped, and even more than $30 \mathrm{~mm}$ in length. The average size of aggregates was $10.6 \pm$ $4.2 \mathrm{~mm}$ in diameter. Aggregates collected at the central station below the chemocline showed a definite increase in size with depth. The dry weight of aggregates varied between 2 and $297 \mu \mathrm{ggg}^{-1}$. Aggregates composed of cyanobacteria exhibited lowest values and large and miscellaneous aggregates close to the shore highest.

\section{Transparent exopolymer particles (TEP)}

Abundances of TEP ranged from $\leq 690$ to $6915 \mathrm{ml}^{-1}$. Numbers were highest at the beginning of September shortly after a decline in numbers of Aphanizomenon ovalisporum filaments (Fig. 1). Aggregates derived from phytoplankton often contained a high portion of alcian blue-stainable material which was still attached to the algae. During the presence of $A$. ovalisporum filaments an inverse relationship between the abundance of TEP and that of cyanobacterial filaments could be noticed. Numbers of TEP always increased shortly after a decrease in abundance of the cyanobacterial filaments. A. ovalisporum surrounded by alcian blue-stainable material was found on natural aggregates from September until mid-October. During the whole period of our study filamentous cyanobacteria were the main producers of TEP.

Microscopical studies of pure cultures of Aphanizomenon ovalisporum growing in mineral media indicated that these algae release individual TEP when

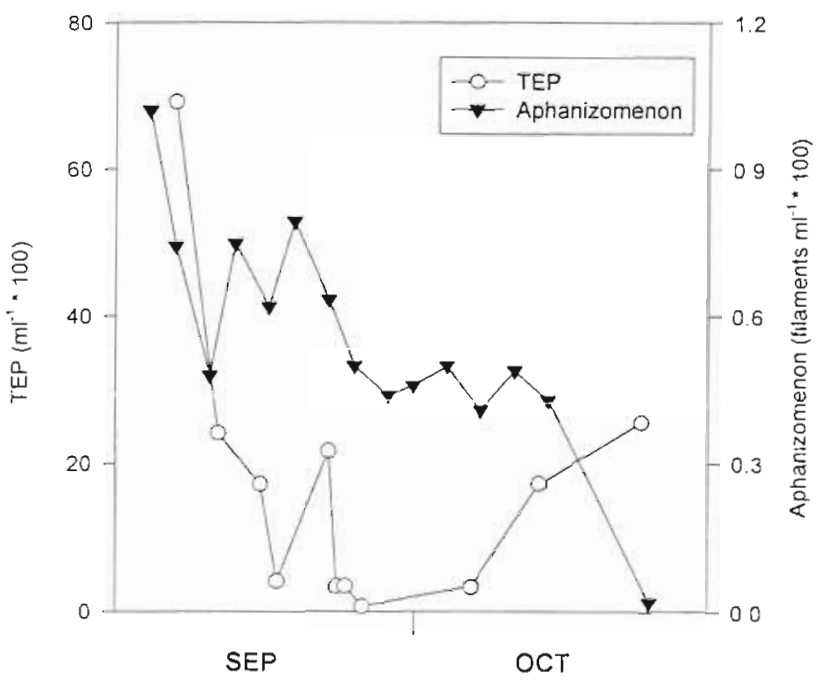

Fig. 1. Numbers of transparent exopolymer particles (TEP) and of filaments of the cyanobacterium Aphanizomenon ovalisporum in Lake Kinneret in fall 1995 
reaching the stationary phase. A large fraction of the TEP produced by cells of $A$. ovalisporum, however, remained attached to the surface of the algae and only a smaller fraction detached as individual TEP. When incubated in rolling tanks, rapid flocculation $(<2 \mathrm{~h})$ of TEP and the filamentous algae occurred.

\section{Formation of aggregates}

The time of formation of aggregates $\geq 3 \mathrm{~mm}$ in diameter was inversely correlated to the amount of POC (Fig. 2). After 2 to $3 \mathrm{~d}$ of incubation, aggregation in the rolling tanks always resulted in the formation of a single aggregate up to $2 \mathrm{~cm}$ in diameter, much larger than the average size of natural aggregates (see above). Characteristics of aggregate formation strongly depended on the source particles, e.g. the POM present in the water sample. Pure cultures of Peridinium gatunense showed preferential aggregation in the senescent stage whereas the non-motile cells of Aphanizomenon ovalisporum which were surrounded by alcian bluestainable material easily aggregated during all phases of growth.

By adding high concentrations of EDTA to water samples collected on 3,12, and 18 October at the central station at $6 \mathrm{~m}$ depth the formation of large aggregates in rolling tanks could be prevented. After $3 \mathrm{~d}$ of incubation only small and very fragile, colourless aggregates were formed whereas in all control experiments without EDTA large, green aggregates ( $>3 \mathrm{~mm}$ in diameter) mainly composed of Aphanizomenon ovalisporum and of green algae (Scenedesmus spp., Staurastrum spp.) appeared after a few hours.

\section{Bacterial colonization}

Abundances of aggregate-associated bacteria in

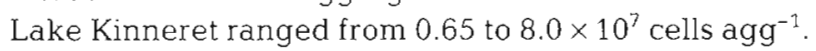
Highest numbers accurred on cyanobacterial aggregates at the end of the bloom in October. The surface of these aggregates was covered by a thick layer of mucopolysaccharides, e.g. alcian blue-stainable material. Aggregates composed of Melosira granulata at the beginning of November showed low bacterial numbers $\left(0.8 \times 10^{7}\right.$ cells agg $\left.^{-1}\right)$. Miscellaneous aggregates close to the shore were more densely colonized and exhibited 5 to $6 \times 10^{7}$ cells agg $^{-1}$.

Numbers of free-living bacteria in the surrounding water ranged between 0.84 and $8.69 \times 10^{6}$ cells $\mathrm{ml}^{-1}$ without any systematic relationship to the occurrence of aggregates. Throughout our study (24 sampling dates) the percentage of aggregate-associated bacteria relative to the total number of bacteria in a given

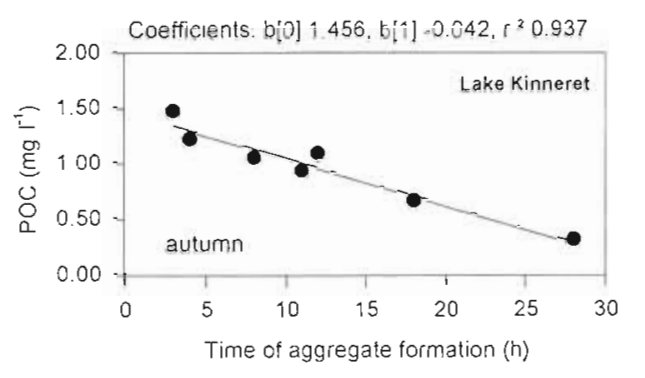

Fig. 2. Relation between POC concentrations at $6 \mathrm{~m}$ depth in Lake Kinneret and the time of aggregate formation $(\geq 3 \mathrm{~mm}$ in diameter) in plexiglass cylinders rolling horizontally at 2 rpm during the study period between September and December 1995

volume of water varied between $<5$ and $30 \%$ with highest percentages at peaks of aggregate abundance. Bacteria on the highly abundant aggregates of Melosira granulata comprised $25 \%$ of total bacterial numbers even though their bacterial colonization was relatively low.

\section{Bacterial activity}

On aggregates the fraction of respiring bacteria relative to total bacteria was significantly higher than in the surrounding water. From 20 to $25 \%$ of all aggregateassociated bacteria were found to be respiratory active whereas only $6 \%$ of all free-living bacteria showed respiratorily activity after $1 \mathrm{~h}$ incubation with CTC.

Aminopeptidase activity on lake snow aggregates ranged between 6 and $42 \mathrm{nmol} \mathrm{agg}^{-1} \mathrm{~h}^{-1}$. On average, aminopeptidase activities were $18 \pm 5 \mathrm{nmol} \mathrm{agg}{ }^{-1} \mathrm{~h}^{-1}$ at $2 \mathrm{~m}(\mathrm{n}=8), 24 \pm 5 \mathrm{nmol} \mathrm{agg}{ }^{-1} \mathrm{~h}^{-1}$ at $15 \mathrm{~m}(\mathrm{n}=8)$, and $7 \pm$ $2 \mathrm{nmol} \mathrm{agg}{ }^{-1} \mathrm{~h}^{-1}$ at $25 \mathrm{~m}$ depth $(\mathrm{n}=7)$. Activities on the same type of aggregate varied with sampling depth and date, e.g. lowest activities of aminopeptidase were observed between 30 and $40 \mathrm{~m}$ depth in the anoxic zone. High activities of aminopeptidase were measured on the compact fecal pellets of the 'Kinneret sardine' Acanthobrama terrae-sanctae, which increased constantly for $24 \mathrm{~h}$ of incubation, reaching $200 \mathrm{nmol}$ $\operatorname{agg}^{-1} \mathrm{~h}^{-1}$. The average aminopeptidase activity in the surrounding water of eutrophic Lake Kinneret was $390 \pm 50 \mathrm{nmol} \mathrm{l}^{-1} \mathrm{~h}^{-1}$ and positively correlated with the amount of particulate matter $\left(\mathrm{r}^{2}=0.93, \mathrm{p}=0.05, \mathrm{n}=\right.$ 23). There were no pronounced differences with depth or season.

Bacterial carbon production was only measured on cyanobacterial aggregates collected at $6 \mathrm{~m}$ depth and ranged between 0.04 and $0.1 \mathrm{ng} \mathrm{C} \mathrm{agg}^{-1} \mathrm{~h}^{-1}$. Comparable rates of bacterial carbon production in the surface water of meso-eutrophic Lake Kinneret were 530 to $940 \mathrm{ng} \mathrm{C} \mathrm{l}^{-1} \mathrm{~h}^{-1}$. 
11 September 1995

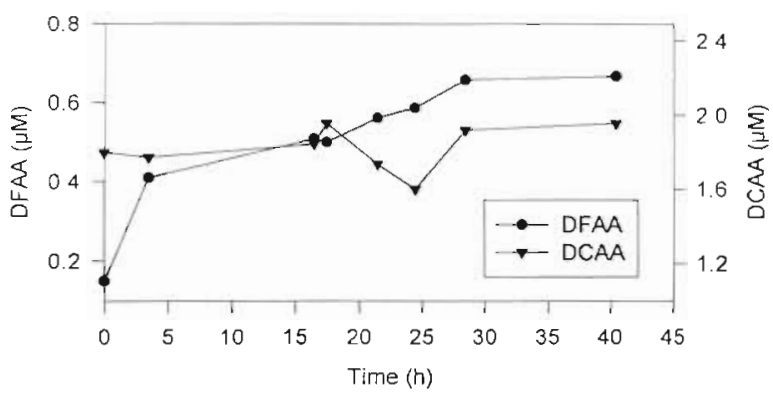

Fig. 3. Time course of the concentrations of dissolved free (DFAA) and combined amino acids (DCAA) during a $40 \mathrm{~h}$ incubation of lab-made lake snow aggregates in rotating $30 \mathrm{ml}$ glass syringes filled with $0.2 \mu \mathrm{m}$-prefiltered lake water

In a single experiment the net release of total dissolved amino acids from lake snow aggregates into the surrounding water during the first $40 \mathrm{~h}$ of incubation was $18 \mathrm{nmol} \mathrm{agg}^{-1} \mathrm{~h}^{-1}$ The release of amino acids from the aggregates which were mainly composed of Aphanizomenon ovalisporum were dominated by DFAA (Fig. 3).

\section{Fish-feeding behavior}

In 20 experiments fish starved for $17 \mathrm{~h}$ ingested suspended aggregates formed of unfiltered lake water in rolling tanks (with up to 22 snaps $\mathrm{fish}^{-1} \mathrm{~min}^{-1}$ ). Water samples for formation of aggregates were taken when Melosira spp. was dominating the phytoplankton assemblage. Aggregates formed by cultivated cyanobacteria Aphanizomenon ovalisporum were not ingested by juvenile fish starved for only $3 \mathrm{~h}$ prior to experiments. Starved fish fed on the cyanobacterial aggregates only with a very low rate 10.2 to 0.6 snaps $\mathrm{fish}^{-1} \mathrm{~min}^{-1}$ ) and subsequent rejection of these aggregates was observed frequently.

Microscopic studies of the fecal pellets produced by fish after ingestion of aggregates from natural lake water revealed that a high percentage of algae (Cosmarium spp., Aphanizomenon spp., and Microcystis spp.) were still autofluorescent and potentially photosynthetically active. Ingested aggregates contained on average $31 \pm 5 \mu \mathrm{g} \mathrm{C}_{\text {org }} \mathrm{mg} \mathrm{DW}^{-1}(32.5 \%)$ whereas fecal pellets freshly produced by the fish had only $20 \pm$ $3 \mu \mathrm{g} \mathrm{C}_{\text {org }} \mathrm{mg} \mathrm{DW}^{-1}(19.8 \%)$.

\section{DISCUSSION}

Our study shows that macroscopic organic aggregates frequently appear in meso-eutrophic, warm Lake Kinneret. The only previous report on such ag- gregates in lakes is from mesotrophic Lake Constance (Grossart \& Simon 1993, Grossart et al. 1997). The present study extends observations to a warm mesoeutrophic lake with considerably different limnological features (Table 1) and thus suggests that aggregates occur in various lakes and have important ecological functions, e.g. the transformation of POM into DOM.

The abundance of lake snow aggregates showed high temporal and vertical variabilities due to differences in phytoplankton and zooplankton communities. Since we studied the occurrence of lake snow aggregates in Lake Kinneret only during a short period in fall we cannot generalize our results for the whole season. The abundance of lake snow aggregates in Lake Kinneret was higher than in mesotrophic Lake Constance ( $\leq 50 \mathrm{agg} \mathrm{l}^{-1}$; Grossart et al. 1997) but the composition of aggregates in the lakes was fairly similar, including phytoplankton debris and miscellaneous matter. However, aggregates of miscellaneous matter frequently found in the anoxic zone of Lake Kinneret were not observed in mesotrophic Lake Constance, which never becomes anoxic. These aggregates with dense colonization of large ( 2 to $4 \mu \mathrm{m}$ ), rod-shaped bacteria were probably the remains of a distinct layer of phototrophic sulfur bacteria (Yacobi et al. 1990). These bacteria are usually observed at the chemocline when the lake is strongly stratified. After increased mixing due to storms in fall this layer is disrupted and flocs of bacterial aggregates presumably sink into the anoxic hypolimnion. We did not observe zooplankton-derived aggregates in fall. Copepods and cladocerans in Lake Kinneret mainly occur from April to July and are smaller than in most temperate lakes (Serruya 1978). Therefore, we expect that zooplankton-derived aggregates may occur earlier in the season but presumably are of minor importance relative to phytodetritus. Colonies of the cyanobacterium Microcystis spp. were a common feature in both lakes with high numbers in the epilimnion whereas aggregates of the filamentous cyanobacterium Aphanizomenon ovalisporum were only observed in Lake Kinneret and were the main constituent of aggregates at the beginning of the investigation period. Blooms of this cyanobacterium were only recently described in Lake Kinneret (Berman 1997). A. ovalisporum led to a rapid formation of aggregates in our rolling tank experiments, which suggests a high potential of aggregation of this algae also in situ. Diatoms, which were a major component of aggregates in Lake Constance (Grossart et al. 1997), are usually a minor constituent of the phytoplankton in Lake Kinneret (Berman et al. 1992). The short-term bloom of Melosira granulata in late October must be seen as a rare event in Lake Kinneret and only the coincidence with a storm at the beginning of November led to the formation of numerous diatom aggregates. 
Aggregates in Lake Kinneret were usually larger than in Lake Constance (10.6 and $5.5 \mathrm{~mm}$, respectively) but never attained sizes as large as in the sea ( $\geq 10 \mathrm{~cm}$; Trent et al. 1978, Herndl 1992). In both lakes, lake snow comprised less dry weight when composed of cyanobacteria and more when formed by miscellaneous matter of benthic origin. In contrast to Lake Constance, aggregates formed by resuspension of littoral sediments in Lake Kinneret comprised a high percentage of still living algae and were densely colonized by bacteria.

Dynamics of aggregates were most pronounced in the littoral zone of Lake Kinneret where we observed diurnal changes in aggregate abundance due to the regular daily wind patterns which are a prominent feature of the lake in summer and fall (Serruya 1978). These results indicate that wind-induced turbulence and sediment resuspension, e.g. aggregate formation, is of particular significance in lakes with a pronounced littoral zone. Wind-induced turbulences, however, led to formation of aggregates also in the pelagic zone of Lake Constance, but not as regularly as in Lake Kinneret (Grossart et al. 1997).

The time required for aggregate formation was inversely correlated with the concentration of POC both in Lake Kinneret and Lake Constance (Grossart et al. 1997). The slope of this regression, however, was relatively steeper in Lake Kinneret, indicating the higher potential of aggregation in this lake. Besides the enhanced POC concentration, another factor explaining the higher aggregation potential in Lake Kinneret was the higher concentrations of TEP. Maximum numbers of individual TEP were $6915 \mathrm{ml}^{-1}$ in Lake Kinneret as compared to $2300 \mathrm{ml}^{-1}$ in Lake Constance. Further, the relatively higher salinity in Lake Kinneret as compared to Lake Constance (Table 1) presumably led to the enhanced aggregation potential. The importance of salinity for flocculation, as in estuaries, is a well-known phenomenon (Eisma 1993). BY adding high concentrations of EDTA in some of our lab experiments we always observed reduced aggregation. Being a chelator for cations, EDTA changes the surface properties of particles and efficiently prevents coagulation by TEP (Decho 1990) and other organic material (Weilenmann et al. 1989). Thus, we assume that the enhanced potential of aggregate formation in Lake Kinneret is the result of high concentrations of POC, TEP, and cations.

The bacterial colonization of aggregates was dense and typical as compared to aggregates from other environments. Numbers were in the same range as those on aggregates in Lake Constance (Grossart \& Simon unpubl. a) and on marine snow aggregates (e.g. Alldredge \& Gotschalk 1990). The dense colonization of lake snow aggregates in Lake Kinneret was also reflected by high rates of aminopeptidase activities. As in Lake Constance (Grossart \& Simon unpubl. a) rates were highest at $15 \mathrm{~m}$ even though statistically not significant. The very low activities of aminopeptidase which were observed between 30 and $40 \mathrm{~m}$ in the anoxic zone of Lake Kinneret are consistent with this pattern but may be biased by methodological problems of measuring the activity in the anoxic environment. The high activities of aminopeptidase on lake snow aggregates were consistent with a substantial net release of amino acids from aggregates. The release rate of this single experiment was in the same range as rates of similar experiments carried out in Lake Constance (Grossart \& Simon unpubl. a) and is a further indication of the high turnover and release of labile organic matter of organic aggregates (Smith et al. 1992). Interestingly, in Lake Kinneret the release occurred as DFAA whereas in Lake Constance and the marine environment release was dominated by DCAA. Because we performed only 1 experiment with cyanobacterial aggregates we are not able to decide whether this difference is due to the different environment or the different type of aggregate.

The decomposition of aggregates is not exclusively due to microbial solubilization. In addition, physical disaggregation, chemical dissolution and biological oxidation of the attached microflora also contribute to degrading aggregates. By applying CTC we were able to demonstrate that 20 to $25 \%$ of all aggregate-associated bacteria were respiring. This proportion is lower than that found in Lake Constance (Grossart \& Simon unpubl. a) but nevertheless indicates that bacteria on aggregates in Lake Kinneret are actively respiring a fraction of the aggregate-associated organic matter. The significance of respiration of aggregate-associated microbes for decomposing lake snow aggregates and smaller particulate organic matter in Lake Kinneret and Lake Constance has also been shown by direct measurements of oxygen consumption (Parparov et al. unpubl.). In fact, in a few experiments it has been demonstrated that microbial respiration and solubilization are of similar importance for the decomposition of lake snow aggregates (Berman et al. 1997).

Our fish feeding experiments show that juvenile Acanthobrama terrae-sanctae and $A$. lissneri were able to feed on lake snow aggregates. They selectively ingested those aggregates which were not composed of cyanobacteria and rejected the latter. The reduced percentage of organic carbon in the fecal pellets of the fish as compared to the ingested aggregates demonstrates that the fish digested about one third of the organic carbon of the ingested aggregates. Feeding on aggregates by juvenile mullet in the sea was recently reported by Larson \& Shanks (1996) who found that organic matter and total amino acids were assimilated 
with high efficiencies by these fish but that the diet of marine snow did not lead to positive growth. These notions suggest that lake snow aggregates may be a food source for fish neglected so far. Through the ingestion of these aggregates a rapid and efficient transformation of protein-rich microbial biomass to higher trophic levels could be mediated providing a short-cut between the 'microbial loop' (Azam et al. 1983) and the top levels of the 'classical food chain'. In particular in the littoral zone of lakes and the ocean, where the abundance of aggregates is high, they may contribute a substantial portion of food to juvenile fish. Thus, macroscopic organic aggregates in the ocean as well as in lakes are not only vehicles of vertical transport of POM and are decomposed by microorganisms but also provide a recycling of detrital material to higher trophic levels of the aquatic food web. Processes associated with macroscopic organic aggregates should be generally regarded as common and important constituents not only in the sea but also in limnetic environments.

Acknowledgements. We thank T. Zohary and T. Fischbein for counting numbers of Aphanizomenon filaments. We are especially grateful to A. Parparov for stimulating discussions and invaluable assistance in the lab. Studies in Lake Kinneret were enabled by 2 scholarships endowed by Förderkreis der Universitäten Konstanz und Tel Aviv (H.P.G., K.P.) and by Grant No. GR0142 from DISUM-BMFT (German Israel Ecological Research, Israel Ministry of Science and Art) to T.B. and M.S.

\section{LITERATURE CITED}

Alldredge AL (1979) The chemical composition of macroscopic aggregates in two neritic seas. Limnol Oceanogr 24 : $855-866$

Alldredge AL, Cohen Y (1987) Can microscale chemical patches persist in the sea? Microelectrode study of marine snow, fecal pellets. Science 235:689-691

Alldredge AL, Cox JL (1982) Primary productivity and chemical composition of marine snow in surface waters of the Southern California Bight. J Mar Res 40:517-527

Alldredge AL, Gotschalk CC (1990) The relative contribution of marine snow of different origins to biological processes in coastal waters. Cont Shelf Res 10:41-58

Alldredge AL, Silver MW (1988) Characteristics, dynamics and significance of marine snow. Prog Oceanogr 20:41-82

Azam F, Fenchel T, Field JG, Gray JS, Meyer-Rejl LA, Thingstad $F$ (1983) The ecological role of water-column microbes in the sea. Mar Ecol Prog Ser 10:257-263

Berman T (1997) Dissolved organic nitrogen utilization by an Aphanizomenon bloom in Lake Kinneret. J Plankton Res 19:577-586

Berman T, Simon M, Parparov A (1997) An approach to evaIuate carbon fluxes during formation and breakdown of aquatic particulates. Aquatic Sciences Meeting, Santa Fe, USA. The American Society of Limnology and Oceanography, Lawrence, KS, p 97 (abstract)

Berman T, Stone L, Yacobi YZ, Kaplan B, Schlichter M, Nishri
A, Pollingher U (1.995) Primary production and phytoplankton in Lake Kinneret: a long-term record (19721993). Limnol Oceanogr 40:1064-1076

Berman T, Yacobi YZ, Pollingher U (1992) Lake Kinneret phytoplankton: stability and variability during twenty years (1970-1989). Aquat Sci 54:104-127

Decho AW (1990) Microbial exopolymer secretions in ocean environments: their role(s) in food webs and marine processes. Oceanogr Mar Biol Annu Rev 28:73-153

Eisma D (1993) Suspended matter in the aquatic environment. Springer-Verlag, Berlin

Fowler SW, Knauer GA (1986) Role of large particles in the transport of elements and organic compounds through the oceanic water column. Prog Oceanogr 16:147-194

Gotschalk CC. Alldredge AL (1989) Enhanced primary production and nutrient regeneration within aggregated marine diatoms. Mar Biol 103:119-129

Grossart HP, Simon M (1993) Limnetic macroscopic organic aggregates (lake snow): occurrence, characteristics, and microbial dynamics in Lake Constance. Limnol Oceanogr 38:532-546

Grossart HP, Simon M, Logan BE (1997) Formation of macroscopic organic aggregates (lake snow) in a large lake: the significance of transparent exopoly-saccharide particles (TEP), phyto- and zooplankton. Limnol Oceanogr (in press)

Herndl GJ (1992) Marine snow in the Northern Adriatic Sea: possible causes and consequences for a shallow ecosystem. Mar Microb Food Webs 6:149-172

Hoppe HG, Kim SJ, Gocke K (1988) Microbial decomposition in aquatic environments Combined process of extracellular enzyme activity and substrate uptake. Appl Environ Microbiol 54:784-790

Jones G (1979) A guide for estimating microbial numbers and biomass in freshwater. Freshwat Biol Assoc Sci Publ 19

Kirchman DL, K'Nees E, Hodson R (1985) Leucine incorporation and its potential as a measure of protein synthesis by bacteria in natural aquatic systems. Appl Environ Microbiol 49:599-607

Larson ET, Shanks AL (1996) Consumption of marine snow by two species of juvenile mullet and its contribution to their growth. Mar Ecol Prog Ser 130:19-28

Logan BE, Grossart HP, Simon M (1994) Direct observation of phytoplankton, TEP, and aggregates on polycarbonate filters using brightfield microscopy. J Plankton Res 16: $1811-1815$

Parsons TR, Maita Y, Lalli CM (1984) A manual of chemical and biological methods for seawater analysis. Pergamon Press, Oxford

Porter KG, Feig YS (1980) DAPI for identifying and counting aquatic microflora. Limnol Oceanogr 25:943-948

Prézelin BB, Alldredge A.L (1983) Primary production of marine snow during and after an upwelling event. Limnol Oceanogr 28:1156-1167

Schaule G. Flemming HC, Ridgway HF (1993) Use of 5cyano-2,3-ditolyl tetrazolium chloride (CTC) for quantifying planktonic and sessile respiring bacteria in drinking water. Appl Environ Microbiol 59:3850-3857

Serruya C (ed) (1978) Lake Kinneret. Monogr Biol 32

Shanks AL, Edmondson EW (1989) Laboratory-made artificial marine snow: a biological model of the real thing. Mar Biol 101:463-470

Shanks AL, Trent D (1979) Marine snow: microscale nutrient patches Limnol Oceanogr 24:850-854

Simon M, Azam F (1989) Protein content and protein synthesis rates of planktonic marine bacteria. Mar Ecol Prog Ser 65:205-211 
Smith DC, Simon M, Alldredge AL, Azam F (1992) Intense hydrolytic enzyme activitiy on marine aggregates and its implications for rapid particle dissolution. Nature 359:139-142

Trent JD, Shanks AL, Silver MW (1978) In situ laboratory measurements on macroscopic aggregates in Monterey Bay, California. Limnol Oceanogr 23:626-635

Urrère MA, Knauer GA (1981) Zooplankton fecal pellet fluxes and vertical transport of particulate organic material in the pelagic environment. J Plankton Res 3:369-387

Utermohl H (1958) Zur Vervollkommnung der quantitativen Phytoplankton-Methodik. Mitt Internat Verein Limnol 9: $1-38$

Editorial responsibility: Farooq Azam, La Jolla, California, USA
Velji MJ, Albright LJJ (1986) Microscopic enumeration of attached and free-living bacteria of seawater, marine sediment, fecal matter, and kelp blade samples following pyrophosphate and ultrasonic treatments. Can J Microbiol 32:121-126

Weilenmann U, O'Melia CR, Stumm W (1989) Particle transport in lakes: models and measurements. Limnol Oceanogr 34:3-18

Yacobi Y, Eckert W, Trüper HG, Berman T (1990) High performance liquid chromatography detection of phototrophic pigments in aquatic environments. Microb Ecol 19 : $127-136$

Submitted: September 28, 1996; Accepted: August 7, 1997 Proofs received from author(s): September 24, 1997 